\title{
A Sentiment Based Text Analysis of the Perception of Chinese Infrastructure Development in Africa: Cases from Nigeria and Ethiopia
}

\author{
Dramane Thiombiano $^{1} \&$ Ahmet Yiğitalp TULGA ${ }^{2}$ \\ ${ }^{1}$ Assistant Professor at the International Master Program in Asia-Pacific Affairs, National Sun Yat-sen University, Taiwan \\ ${ }^{2}$ Ph.D. Candidate at Institute of Political Science at National Sun Yat Sen University, Taiwan \\ Correspondence: Dramane Thiombiano, Assistant Professor at the International Master Program in Asia-Pacific Affairs, \\ National Sun Yat-sen University, Taiwan.
}

Received: September 23, 2021

doi:10.11114/ijsss.v10i1.5359

\author{
Accepted: November 1, 2021 \\ Available online: November 5, 2021 \\ URL: https://doi.org/10.11114/ijsss.v10i1.5359
}

\begin{abstract}
This paper investigates the perceptions of Africans on Chinese infrastructure development in Nigeria and Ethiopia. Using a sentiment-based text analysis methodology, this paper attempts to understand the perceptions and sentiments of Nigerians and Ethiopians on Chinese infrastructure projects. For this purpose, we choose Nigeria and Ethiopia as important destinations of Chinese investment in Africa. Africa is not only rich in natural resources; it also possesses a young population that makes the bulk of the working force. Despite its rapid GDP growth and growing urbanization, the continent is still entangled in the midst of underdevelopment, poverty and an acute lack of infrastructure to stimulate and sustain this economic development. China's investment in the continent is trying to tackle this infrastructure bottleneck by investing in the building of infrastructures such as roads, railways, ports and highways. The results show some overall positive popular sentiments towards Chinese infrastructure projects from both countries. To conclude, we argue for a need of more scrutiny from the parts of the leadership in Africa given the potential issues related to Chinese infrastructure projects in Africa.
\end{abstract}

Keywords: infrastructure development, Africa, China, Ethiopia, Nigeria, sentiment-based text analysis

\section{Introduction}

Sub-Saharan Africa belongs to the part of the world that has always been portrayed as underdeveloped and infested by disease, poverty and wars. Africa is usually associated with the expression "four horsemen of Africa's Apocalypse," which describes Africa as a Pandora's box of wars, diseases, poverty and corruption (Nathan, 2000). These connotations also bring to our mind the expression of a failed and doomed continent that has "gotten off to a bad start" (Dumont, 1963). These perceptions are corroborated by the widespread poverty on the continent, which after many years of foreign aid and a trillion US dollars spent on Official Development Assistance programs is still struggling with poverty, leading many scholars to question the effectiveness of aid.

The emergence of China as a new actor and pragmatic partner has brought opportunities but also challenges. Opportunities stem from the development of much needed infrastructure to sustain economic development. Challenges might come from the fear of overreliance on China.

The development of infrastructure (transports, energy, etc) constitutes a major component of Chinese cooperation with Africa (Shirley, 2021). In Sub-Saharan Africa suffer from infrastructure deficit. The continent lags behind other developing regions in virtually all infrastructure sectors, be it electricity, road or railroad performance (Leggelo-Padilla, 2017). The biggest infrastructures date back from the colonial era and have been worn out either by time, weather, or poor maintenance. Transports, energy, information technologies, and water infrastructures are crucial to the development of African countries. China's cooperation with Africa in the development of infrastructure such as roads, telecommunications, bridges, railways, has positively contributed to the continent's needs of infrastructure. Chinese companies engaged in Africa usually offer package deals for natural resource extractions, contrary to western extracting companies, which are usually reluctant to venture into infrastructure development. For instance, Guinea-Conakry, through its partnership with China, had successfully negotiated the building of the infrastructures in exchange for bauxite extraction (Michel \& Beuret, 2009). As Ousmane Sylla, the Guinean minister of mine and energy puts it: "The Chinese...they are the only ones who offer us 'packages' deal or turnkey contracts: a mine, a hydroelectric dam, a 
railroad, and a refinery- all financed by the China EXIMBANK” (Michel \& Beuret, 2009).

This investment in Africa's infrastructure has facilitated technology transfers, complementing the West's focus on political and economic reforms on the continent (Haroz, 2011).

According to the China-Africa white paper report, the amount of construction done by Chinese companies in Africa has reached US $\$ 40.83$ billion, making Africa the second largest overseas contract market of China for four straight years since 2009 (Economic, 2013). China has already overtaken the United States to be become the largest investor in Africa (Shirley, 2011).

This cooperation with China, has partially helped to solve the issue of shortage of infrastructure, easing by this token communication between African countries at a regional and local level (Bluhm et al., 2018). For instance, in Angola, in exchange for crude oil, China has provided loans with low interest rates to the Angolan government and helped in the reconstruction of infrastructures destroyed during the protracted civil war (Indira \& Alex, 2008). Such infrastructures include roads, railways construction and rehabilitation and housing, etc. China has contributed to the rehabilitation of the once destroyed railway system linking the eastern and western part of Angola.

In Eastern Africa, China's communication enterprises have also contributed to the improvement of communication through the building of a fiber-optic transmission backbone network in Tanzania that will not only improve communication in this country but in the region as a whole (Meibo \& Xie, 2012).

Thus, it goes without saying that Chinese infrastructure development has positive impacts on Africa's development. The provision of infrastructure to African countries is contributing to their economic growth and their integration into the global economy. Chinese growing economy has increased its needs for natural resources, and as for Africa, developing its infrastructure will further develop its potential as not only a natural resource provider but also enhance its industrialization. The construction of infrastructures can also lead to technology transfer whereby African countries learn from China, a developing country itself, that has been able to lift half a million people out of poverty. In this vein, Calestous Juma, a Harvard professor argued that China is contributing to technology transfer and higher technological education and is similarly re-establishing Africa as a source of valuable commodities for the global market (Marshall, 2011).

However, this picture should be painted so rosy. Communication issues between Africans and Chinese due to language barriers could undermine this transfer of technology. This could be solved by the provision of adequate Chinese language training to Africans engineers or key people working with their Chinese counterparts. In addition to communication, there are also issues such as debt sustainability, good governance, and environmental impact that could hinder the benefits of these infrastructure projects. Through a sentiment-based text analysis, this paper attempts to understands the perceptions and sentiments of Nigerians and Ethiopians citizens on Chinese infrastructure projects. 2.

\section{Background of the Study}

The development of infrastructure is an important element in Sino-African relations. China's growing competitiveness in the sector has made it the major partner and one of the most prominent developers of infrastructure on the continent. African governments usually see China's investment in infrastructure as positive, praising the positive impact of these infrastructures on the expansion of economic activities, the creation of jobs for local people, and improvements in the transportation networks (Hanauer \& Morris, 2014).

\subsection{Why Nigeria and Ethiopia?}

The rationale behind our choice of Nigeria and Ethiopia stems from the fact that both countries are the most populous nations on the continent. They are among the biggest economies on the continent and ranked respectively first and third in terms of Chinese investment in Africa (Mariama, 2018).

Ethiopia and Nigeria, just like many countries on the continent, are also staunch supporters of China and are considered strategic partners of China. In Ethiopia, Chinese investment in the development of infrastructure has heavily contributed to the positive image Ethiopians have of China (Alemayehu \& Atenafu, 2010). As in the words of the spokesperson of the prime minister of Ethiopia, "China is a powerful partner for Ethiopia's economic development, with an enormous investment in Ethiopia's infrastructure development and transfer of technical expertise as well” (Xinhua, 2020). In addition, a survey on countries' opinion on China, conducted by Pew Research Center in 2015, showed 75\% of Ethiopians have a favorable opinion of China (PEW, 2021). With its growing population, Ethiopia has looked up to China as a model of development and courted it for infrastructure projects. Examples of infrastructure development include the US\$86 million ring road, the Gotera Intersection (US\$12.7 million), Ethiopia's first six-lane highway (US\$800 million), and the Ethio-Djibouti Railways line (US\$4 billion), which connects the landlocked country to the sea (Jenni, 2018). At the top of this, China has also built the first metro system network in Addis Ababa and huge skyscrapers that are changing the face of the city. This has enhanced people's positive perception of China as a 
developer and pragmatic partner and a model to emulate (Jenni, 2018).

In 2014 BBC World Service Poll, 80\% of Nigerians view China's influence positively, with only $10 \%$ expressing a negative view (BBC, 2021). Another study by Pew Research shows the positive perception people living near a belt and road have of China (Dennis, 2020). According to the study, when the construction of the transport infrastructure started, $62 \%$ of Nigerians living within 150 kilometers (93 miles) of the project expressed a positive perception of China. After completion of the project the percentage increased to $71 \%$.

In 2019, a survey by the Pew Center (figure 1), highlighted the positive views that majority of Nigerians have towards China regarding its economy and investment on the continent. As stated by the survey, $83 \%$ of Nigerians believe China's growing economy is good for Nigeria. As for China's investment in Nigeria, $82 \%$ believed it is a good thing given that it will lead to the creation of new jobs (Silver et al., 2019).

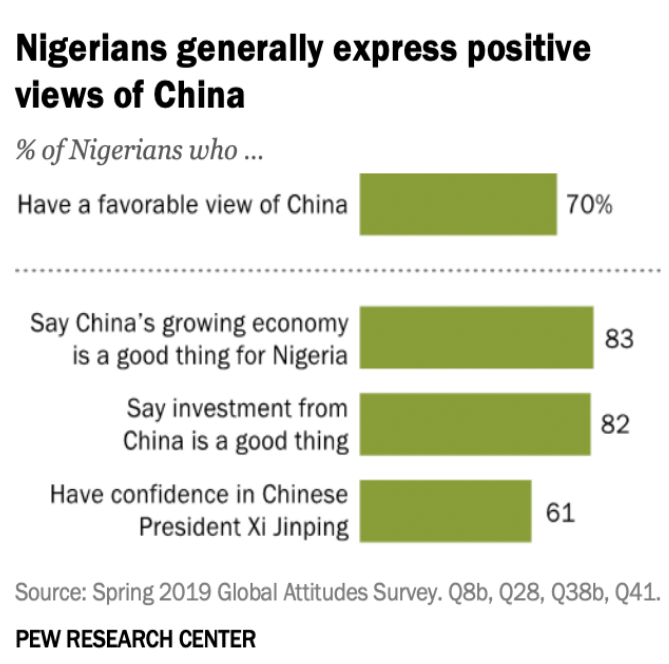

Figure 1. Nigerians' view on China (PEW, 2019)

\section{Objectives of the study}

This study aims to show the importance of infrastructure for Africa, and the benefits of Chinese investment in infrastructures on the continent. Most importantly, this study aims to investigate the opinions Africans have on the infrastructures developed by China through a sentiment-based text analysis. Official account of China's infrastructure development on the continent usually positively praise China as a valuable partner. To have a balanced perception on the issue, adding the perceptions of ordinary citizens and people who are not government officials, is of paramount importance. Being sometimes those to whom these infrastructures directly benefit the most, understanding their sentiments on the issue is very important.

\section{Literature Review: Chinese infrastructure projects in Nigeria and Ethiopia}

\subsection{Chinese Infrastructure Projects in Nigeria}

Since its independence, a compelling constraint that had negatively impacted Nigeria's development and growth potential is its underdeveloped and crippling infrastructure. For instance, the Nigerian transport sector is contributing just $1.41 \%$ to the country's GDP according to the Central Bank of Nigeria. Also, as one of the most populous countries on the continent, Nigeria will have to provide energy and infrastructure to its population at a value of US\$166 billion per year. The consequences of an underdeveloped infrastructure system are linked to the limited movement of people, goods and investments. Chinese cooperation in the infrastructure projects has had an immense impact on the country's development (Olamide, 2017). Reckoning the importance of infrastructure for his country and the considerable impact Chinese infrastructure development has on the country, Nigerian president, Muhammadu Buhari stipulates (Okereke, 2017):

"We thank China for its support to us in various ways; in building of rail, road, power, defense, and many others. You are helping us to reduce our severe infrastructural deficits, and we are glad. There cannot be sustainable development without infrastructural development." 
This improvement in infrastructure development has flared up after Nigeria has joined the Belt and Road Initiative (Ehizuelen \& Abdi, 2018; Cabestan, 2019). Chinese contribution to the improvement of infrastructure in Nigeria include: rails and roads, seaports and airports. The recent infrastructure projects include:

- The modernization of the Abuja-Kaduna Rail Line completed in December 2014 with China's support.

- In 2018, the construction of 312Km of road between Lagos and Ibanda built at US \$1.53 billion by China Civil and Engineering Construction Company (CCECC)

- $300 \mathrm{~km}$ line between Lagos and Benin City, 615km high-speed Lagos-Abuja line; $1675 \mathrm{~km}$ Port Harcourt-Maiduguri line.

To improve the capacity of airport in the country, the aviation sector has also benefited from:

A US\$500 million loan from the Chinese Exim Bank to construct new terminals at all four Nigerian international airports and upgrades to 22 of its federal airports. In addition, agreements and Memoranda of Understanding (MOU) have been have been signed between Nigeria and China in the domain of aviation cooperation, scientific and technological cooperation, solar polar cooperation, building of mining plants, the construction of a greenfield expressway for Abuja-Ibadan-Lagos worth US\$1 billion dollars (Olamide, 2017).

In addition to the building of infrastructure, China has also pledged loans to finance infrastructure projects in Nigeria. Concomitantly, the two countries through their banks (Industrial Commercial Bank of China LTD., and the Central Bank of Nigeria) have signed a currency swap deal by trading in yuan instead of the dollar. This will contribute to facilitate trade between the two countries.

\subsection{Chinese Infrastructure Projects in Ethiopia}

Ethiopia is a landlocked and Africa's second most populous country. It has a population of 114 million people, ranking $12^{\text {th }}$ in the list of countries by population. The population is young with a median age of 19.5 years (Haile, 2004; Hailemariam et al., 2020). Ranked among the poorest countries in Africa in the 2000s, Ethiopia is now among its fastest growing economies at an annual rate of $10 \%$ per year (Vivien \& Elvira, 2010). As a result, the percentage of Ethiopian living in extreme poverty has decreased from 55.3\% in 2000 to 33.5\% in 2011 (Nicholas, 2017). Ethiopia is the among the top destination of Chinese ODI in Africa and constitutes an attractive production location for Chinese firms (Nicholas, 2017).

Infrastructure development has played an important role in this miracle. According to the Africa Infrastructure Country Diagnostic (AICD), an improvement in the country's infrastructure has contributed to a 0.6 percentage of annual per capita GDP growth. This could increase to $3.8 \%$ if the country's infrastructure development could reach the level of Mauritius (Nicholas, 2017). As a landlocked country, Ethiopia needs to improve its infrastructure in order to support its growing economy. Ethiopia's spending on infrastructure project has reached $\$ 15$ billion partnering with China, the World Bank, the European Union, and the African Financial Development Bank (Taye et al., 2016). China's development of infrastructure in Ethiopia has contributed to the country's integration into the world economy. China's investment in Ethiopia totaled US\$4.7 billion between 2009 through 2012 (Nicholas, 2017). Chinese investment in the country is mainly concentrated in the construction of infrastructures such as roads, railways, telecommunications, industrial parks, power (Nicholas, 2017). Ethiopia is an important partner of China in the Belt and Road Initiative.

China is the dominant developer of Ethiopia's infrastructure, and has been active in the building of roads, railways, lines, dams, etc.

For instance, in 2017, a US\$4 billion railway project was constructed to connect landlocked Ethiopia to Djibouti (Morlin-Yron, 2017). The railways are 752 kilometers and reduces travel time from Ethiopia to Djibouti from three days to just 12 hours (Seyoum \& Lin, 2015; Chakrabarty, 2016). This reduction will have a positive impact on trade flows and transportation costs.

Other examples of China's involvement invested in infrastructure projects include:

- The building of the Tekezé Arch Dam in 2009. It considered Africa's tallest dam with the capacity to generate 300 MW of electricity.

- A US\$400 million metro rail system in Addis Ababa in 2015, which is benefiting millions of urban commuters.

- Chinese firms are also building over two-thirds of the roads in Ethiopia, including the prominent Addis Ababa Ring Road.

\section{Theoretical Framework}

Infrastructures are the backbone of a sustainable economic development. What is an infrastructure? Dictionary.com defines it as "the fundamental facilities and systems serving a country, city, or area, as transportation and 
communication systems, power plants, and schools" (Dictionary, 2021). It includes facilities such as roads, railways, bridges, electrical grids, and telecommunications, etc. They are indispensable for a good functioning of countries economy because they provide the necessary commodity and services to sustain and enhance people's life and society as a whole (Fulmer, 2009). The literature on infrastructure unanimously recognized the important impact it has on economic development. Apart from that, opinions on the magnitude and causality of this impact has long been debated by scholars (Torrisi, 2009). Our objective will not be to speculate on these different perceptions, but we will rather argue on the impact and importance of infrastructures on sub-Saharan Africa. Aschauer (1989) in his study on the relation between infrastructure and growth argues that a $1 \%$ increase in investment in public infrastructure will have for consequence-a $0.24 \%$ increase in the output of the private sector. This finding led him to conclude that the decline in productivity growth during the 1970's was largely due to a decline in public investment in infrastructure. His argument was critized by Gramlich (1994), who stipulated that his study was "pretty stratospheric estimates of the marginal product of government capital" (Gramlich, 1994). For Gramlich, a positive impact of infrastructure on productivity forcibly leads to the trade-off between increasing returns of scale and large factors rents (Gramlich, 1994). If we go further as ask the question of the causal relation between infrastructure and productivity which comes first? Some studies argue that increased number of infrastructures derived from increased productivity and economic growth and not the other way around as suggested by Aschauer (Evans \& Karras, 1994). This argument is also supported by Zegeye (2000) who stipulated that infrastructure is a normal good, so that wealthy counties will tend to have more due to their higher level of income (Torrisi, 2009).

\subsection{Contextualizing African Infrastructure}

Infrastructures constitute a key ingredient of a country's prosperity and development. The building of roads, ports, and railways can boost a country's economy, trigger growth and improving by this token the quality of life of its people. Infrastructures can lead to the increase in investment, commerce, education, trade, etc. As Luis Serven argues, "conceptually, infrastructure may affect aggregate output in two main ways: first, directly because infrastructure services enter production as an additional input, and second, because they raise total factor productivity by reducing transaction and other costs thus allowing a more efficient use of conventional productive inputs" (Calderon \& Serven, 2008).

In Africa, infrastructures are critical to productivity and contribute to human development, poverty reduction, and the attainment of the Millennium Development Goals (Ajakaiye \& Ncube, 2010; Ayogu, 2007). They bind together different sectors of the economy, leading to the cohesion within the different production systems of a country.

For instance, transportations infrastructures are important factors to development and economic growth. Most firms (3.6\%) estimate the lack of transport infrastructure as the main hindrance to the development of business on the continent (Zajontz, 2021). In Africa, the poor quality of roads, railways and port infrastructures can increase not only the cost but also the transit times and breakage (Zajontz, 2021). According to the African Development Bank, road freight tariffs per kilometer are two to four times higher in Africa than in the United States and travel time along key export routes are two to four times higher than in Asia (African Development Bank, 2018). According to the World Bank Enterprise Survey (2007-2018), 1.9 per cent of the value of products is lost to breakage or spoilage during shipping to domestic markets in Africa. An increased connectivity would facilitate and grow domestic, regional and international trade, lower the cost of doing business and make African nations more competitive, both within the continent and at global level (African Development Bank, 2018). In addition to transports, the development of an efficient energy supplies could enable firms on the continent to adopt new production techniques and technologies, raise productivity and facilitate the introduction of new economic activities (Donou-Adonsou \& Lim, 2018).

The development of information and communications technologies in Africa could contribute to economic and social progress. These improvements will have the potential to better people's lives in both rural and urban areas. Increasing people's access to internet can contribute immensely to knowledge acquisition, advancing skills and capabilities. However, in sub-Saharan Africa, only 15\% of households have access to internet (Shen, 2015). The region has experienced dramatic benefits from the use of internet. Most Africans consider the advent of internet has having a positive impact on education, especially by reducing the gap between rural and urban populations (Laura \& Courtney, 2018). The internet gives individuals in the developing world a better access to modern economy. With internet, people easily have access to micro-loans and take part in e-banking (Linda, 2019).

Another positive aspect of developing infrastructures in Africa is that they facilitate the provision of goods and services to consumers and also supply intermediate inputs, which will contribute to the production of other sectors of the industry and lead to an overall increase in productivity. As complementary inputs for factors of production (capital, labor and entrepreneurship), infrastructures contribute to the increase of returns on investment, the reduction of production cost and the improvement of transition efficiency. Basic infrastructures therefore, are a prerequisite for the 
economic development of developing regions like sub-Saharan Africa because of their immense contribution to productivity and growth of the economy (Fei, 2020). This process will result in the increase of market size, and the realization of economies of scale at the enterprise level. This in turn will attract private investment, leading to the thriving of the private sector. From a socio-economic perspective, infrastructure development can contribute to the reduction of poverty by improving the living conditions of people in Africa and increasing the opportunities for trade and employment.

With its 1 billion population, its strong market potential, and a vibrant youth, Africa could experience an exponential economic development if basic infrastructures were adequately developed (Gildfred, Ousmane \& Sadhiska, 2021). The recent surge in Chinese investment in the development of infrastructure on the continent comes as an opportunity for its economic development and integration to the world market. This investment in infrastructure development has brought positive economic outcomes for both China and Africa. For Africa, this could lead to a spillover to other sectors of the economy.

Therefore, better infrastructure development in Africa can cause development and equity in developing countries. Empirical studies done by Calderon, Cesar Serven, Luis (2008); Bom and Ligthart (2009) have corroborated the strong correlation between infrastructure development and economic growth. Bom and Ligthart (2009) estimate the elasticity between infrastructure and growth for developed countries to be 0.15 , meaning if infrastructure capital doubles, there will occur a $10 \%$ increase in GDP.

The lack of infrastructure development has always been the Achilles heel of many African countries. In terms of infrastructure development, Sub-Saharan Africa lags behind other developing regions on most standard indicators. According to some estimates, sub-Saharan Africa needs for infrastructure development is about "US $\$ 20$ billion per year and an associated funding gap on the order of US $\$ 10$ billion per year" (Foster, 2009). As Stephen Hayes, president of the Corporate Council on Africa puts it "Infrastructure is ... probably the single most important need for Africa to develop". He goes on, "There's not a single country in Africa that's meeting its current power needs" (Lewis, 2012). Africa is in crucial need of infrastructures, and because of their impressive nature, they are easily perceptible by people.

This crucial need for infrastructure in Africa justifies the positive perception people have of Chinese development of infrastructure on the continent. In 2014-2015, A survey by Afro-barometer was conducted to gather Africans perceptions of China. The findings show a majority (63\%) of African public holds a positive opinion of China's economic and political influence in Africa. The main reason behind this approval is China's infrastructure/development and business investments on the continent (Mogopodi et al., 2016). However, negative perceptions of the quality of Chinese products deteriorated its image among African citizens (Mogopodi et al., 2016). Another survey conducted in 2019/2020, showed people still consider Chinese influence as positive, though the majority leaned towards the United States development model (Folashade \& Edem, 2020). The relative decline of China's image could be explained by the negative perceptions of loans and financial assistance, framed by the 'debt-trap' narrative and allegations of Chinese asset seizures, the growing dominance of China on the African economy (Adisu, Sharkey \& Okoroafo, 2010).

\section{Research Design and Methods}

In this study, the news of Nigerian and Ethiopian newspapers are examined. The unit of analysis of this research is the news about Chinese infrastructure in Nigeria and Ethiopia. The official language of Nigeria is English. Ethiopia's official languages are diverse, and the Ethiopian federal government has recognized 5 languages as official languages. Ethiopia recognizes Amharic, Afaan Oromo, Tigrinya, Somali and Afar as official languages (Shaban, 2020). However, $\mathrm{R}$ computer program doesn't support these local languages, and for this reason, all the news analyzed are selected from English news with the keyword "Chinese Infrastructure".

Three newspapers are selected from each country. Vanguard, Punch and This day live newspapers from Nigeria were selected for analysis. Vanguard is a private newspaper founded in Lagos, Nigeria. Similarly, The Punch, founded in 1971, is the second largest newspaper in the country and is a private newspaper. Finally, The Day is Nigeria's national newspaper.

In the case of Ethiopia, Fortune, Reporter and Ethiopia press agency newspapers are selected for analysis. The Addis Fortune newspaper is a private newspaper and is the country's largest English-language newspaper. On the other hand, Ethiopia Press Agency is the Ethiopian official state newspaper.

These selected newspapers are the most popular newspapers of Nigeria and Ethiopia. The purpose of choosing these newspapers is to reflect the opinions of both the state and the public. Newspapers and mass media are chosen because newspapers and mass media are "amazingly successful" in deciding what average people care about (Cohen, 1963), and research focused on the public agenda-setting role of the media also shows that the most significant evaluations of the topic follow the amount of media attention of a problem (McLaren, Boomgaarden \& Vliegenthart, 2018). 
Graph. 1: Analysis Step

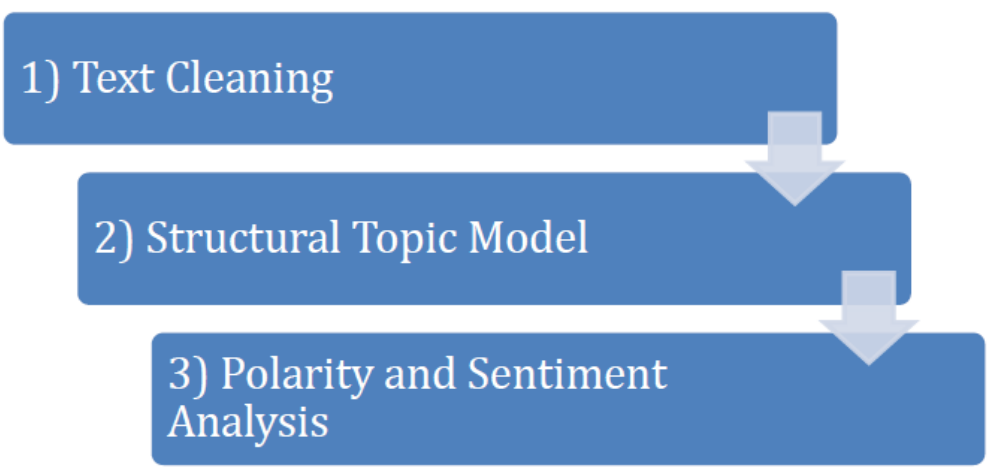

The news published by the selected newspapers are searched on their online websites. The relevant news of the newspapers is taken by web scraping method. With the Selector Gadget tool, the necessary codes of these news for text analysis are obtained. With the "rvest" package in the R computer program, the news with HTML extension are transferred to the R program. As a result, a total of 700 news items are obtained. Utilizing the 700 English news from Nigeria and Ethiopia to assess the impact of Chinese infrastructure in these countries involves three steps. A detailed step to step explanation is of paramount importance. First, the English news would have to be interpreted as a Term-Document Matrix (TDM), built by translating documents to text format; stemming all words from our text data and eliminating punctuation (Manning, Raghavan \& Schütze, 2008). The news from Nigeria and Ethiopia is first cleaned separately and prepared for review. Cleaning of text data is an important process that can take more time than any other stage in the field of text analysis. It is important because we want to delete words and symbols that have no impact on the context of the word. As result of this process, we ought to remove expressions that have no impact on the semantic context of the text that scholars call as "stop words."

Text analysis is pervasive in social science research: conventional media, social media, poll data, and many other outlets lead to a vast volume of text in the digital information century (Catalinac, 2016). The growing number and value in text data have contributed to the development of several methods for the study of such data (Catalinac, 2016). In the second step, following data cleaning, we use the Structural Topic Model (STM). The purpose of the STM is to enable researchers to discover themes and to approximate their relationship to record metadata (Roberts, Stewart \& Tingley, 2019).

We run a variety of concept requirements and calculated the essence of each subject in each specification by reading the word stems and manifestos with the highest likelihood of belonging to each subject. As Lindstedt (2019) suggested, after playing with specifications of between 15 and 100 subjects, we agree on a specification of 20 subjects because 20 topics is one of the lowest specifications that seemed to yield themes that are good quite enough match with our concern (Roberts, Stewart \& Tingley, 2019). Afterwards choosing a list of 20 subjects, we take the following initiatives to maintain that each subject was materially relevant.

As a result, Nigerian news focus on investment, infrastructure, and economic issues such as loan, China, rail, and project (topics $4,9,1$ ). These topics are the top topics in the news. Ethiopian newspapers have been observed to focus on investment and relations issues such as invest, USD, Ethiopia, and China (Topic 18 and Topic 17).

In the last stage of the research, polarity and sentiment analyzes of the selected news are made. Sentiment analysis is a key unit situated in the center of natural language processing, computational linguistics, and text mining (Hu \& Liu, 2004). Nowadays, many studies in the field of social sciences use sentiment analysis method to explain individual decisions in response to textual content (Pröellochs \& Feuerriegel, 2019). This analysis applies to any measure from which the subjective knowledge is derived from the written records. In other terms, it derives the polarity of the view articulated in a continuum ranging from positive to negative. As a consequence, sentiment analysis can also be referred to as opinion analysis or mining (Pang \& Lee, 2008). First, we conduct a sentiment analysis based on the Harvard dictionary. We examine the meaning of textual material in R. This application uses dictionary Harvard IV. As a mathematical method, the above utilizes the regularization of LASSO to pick specific words dependent on an exogenous response vector (Pröellochs \& Feuerriegel, 2019). Dictionary with a list of terms that are good and derogatory according to several dictionaries and one of them is the Harvard dictionary (Pröellochs \& Feuerriegel, 2019). Finally, polarity analysis of news related to Chinese infrastructure aid is made. In this context, it is examined whether the content of the examined news is positive or negative. 


\section{Results}

In the first stage of the research, it was started by cleaning the texts and punctuation marks and unnecessary words were deleted. In the following step, the selected news is divided into topics using the Structural Topic Model Method.

Table 1. Top Topics in Newspaper

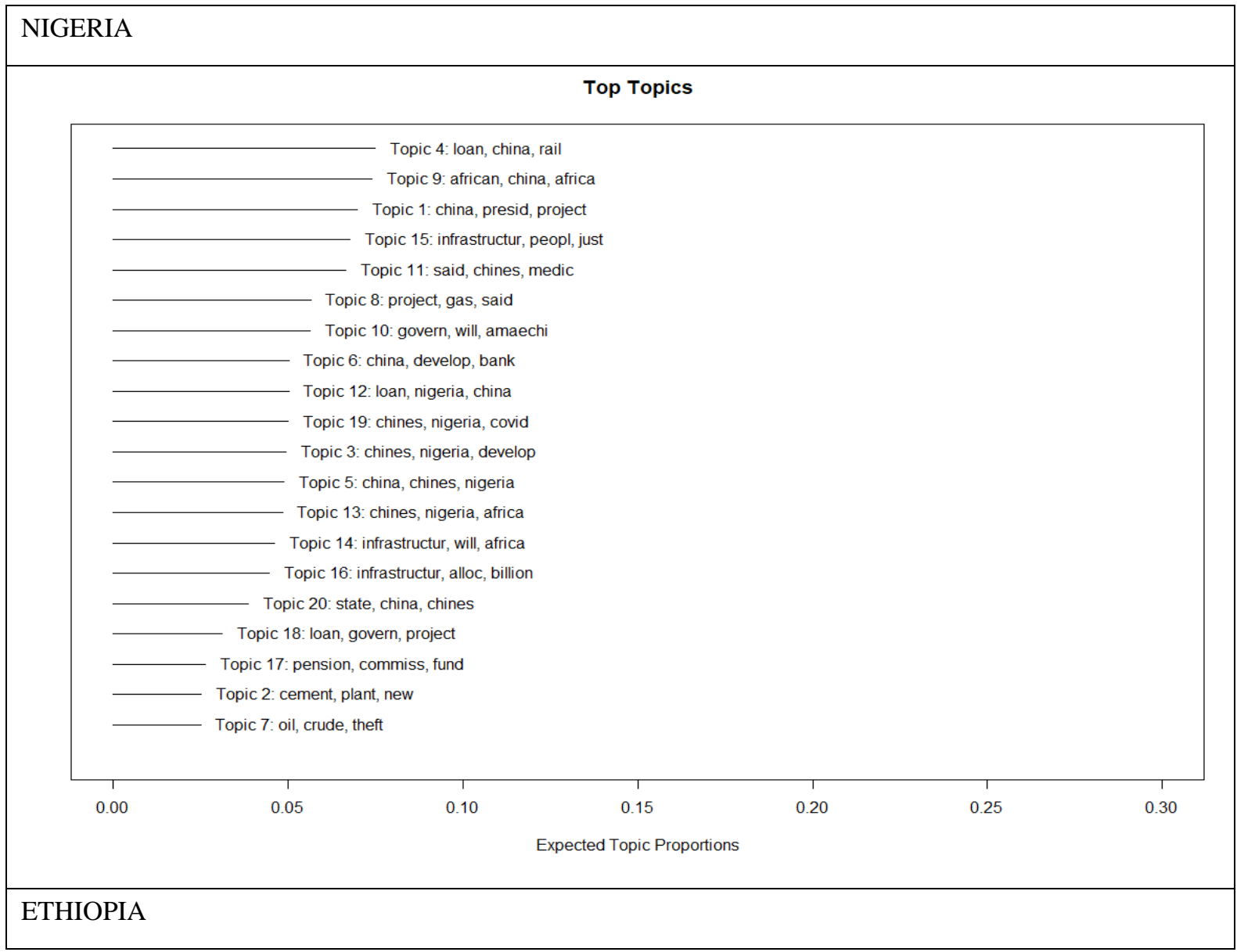




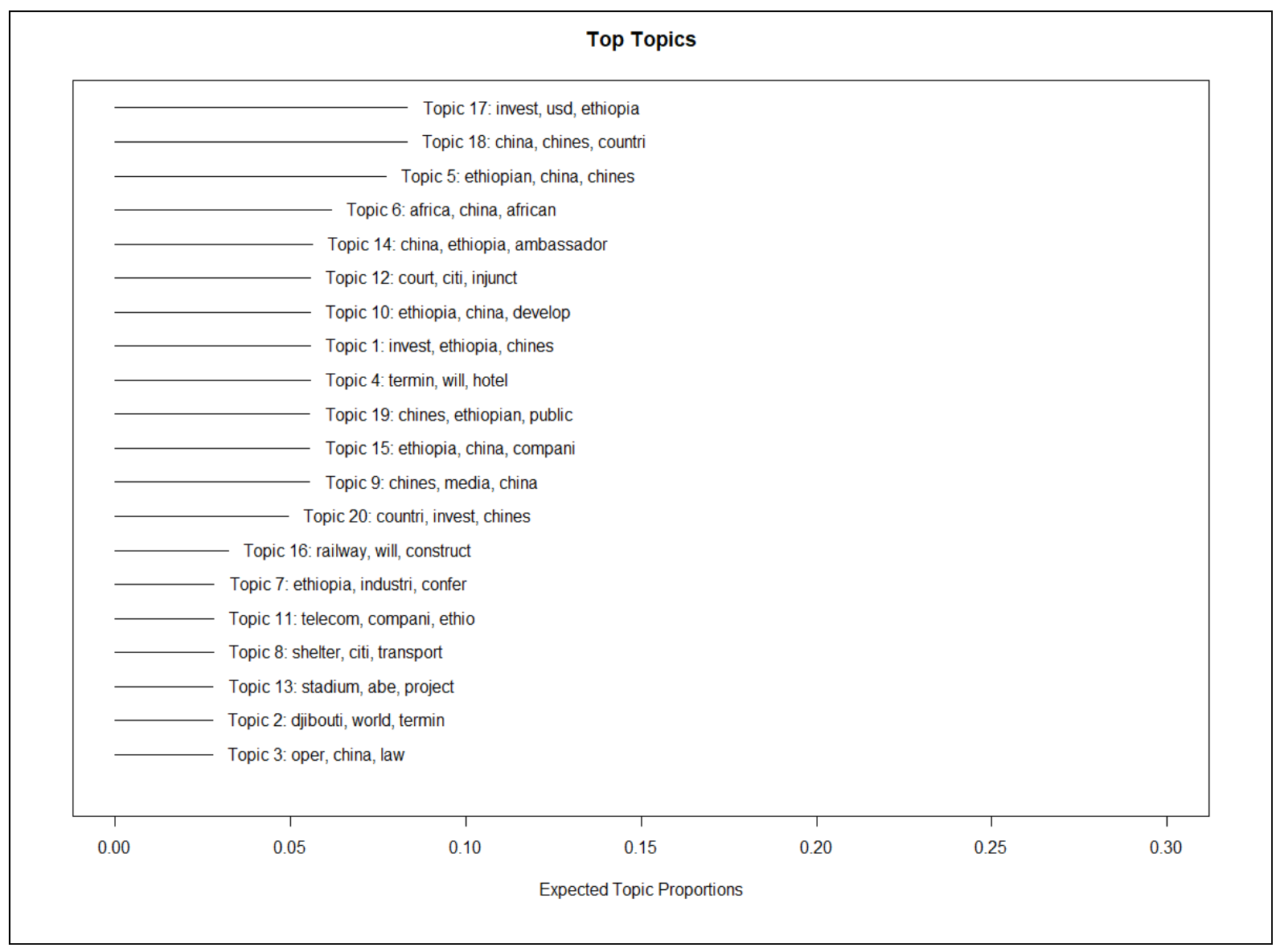

In this step, two dominant topics in Nigerian and Ethiopian newspapers are emphasized, and it is shown which words in these two topics were more related to one covariate value than the other. As a result of this analysis, it is found that the most important topics in Nigerian newspapers about Chinese infrastructure aid and investments are on economy, relations and investment. Likewise, in Ethiopian newspapers, it is found that the two most important subjects focused on investment, relations and economy. 
Table 2. Two Main Topics in Newspaper Analysis

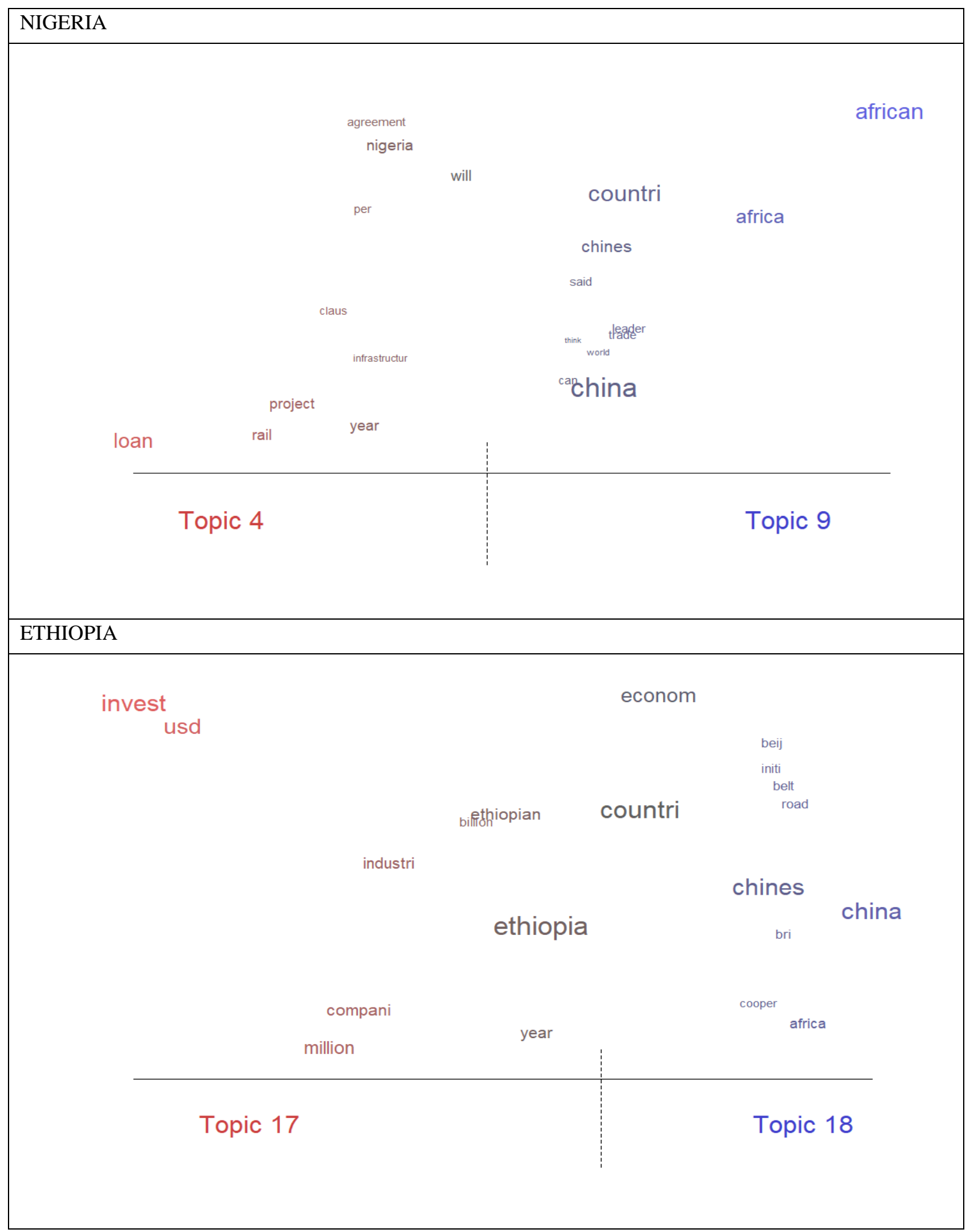

Following the structural topic analysis, sentiment and polarity analyzes are conducted. In this context, first, sentiment analyzes are conducted. We find the sentiment analysis results of Nigerian and Ethiopian newspapers to be quite similar. It has been found that the news in Nigerian newspapers about Chinese infrastructure aid and investment is predominantly related to trust. Following Trust sentiment, there is anticipation and fear. When the words that cause the feeling of fear are examined, it is found that words such as pandemic, contagious, unlawful, damage, socialist and slave increase the sentiment of fear. 
Table 3. Sentiment Analysis of Nigerian Newspaper

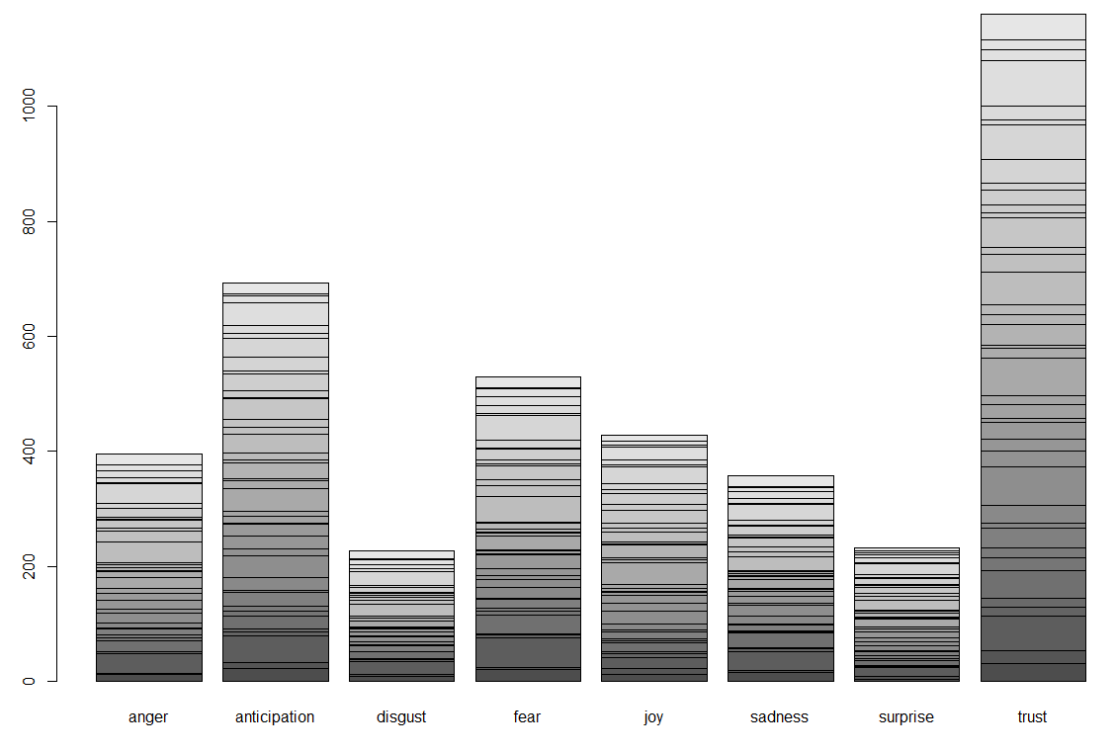

Similarly, it has been found that the predominant sentiment is trust in the news about Chinese infrastructure investments and aid in Ethiopian newspapers. It is seen that the feelings of anticipation follow the feeling of trust. The third emotion is fear in sentiment analysis of newspaper. It has been found that words such as pandemic, unequal, instability and illegal are words that increase the sense of fear. On the other hand, when we look at the words that increase trust, it is seen that there are words such as cooperation, exchange, and trade.

As a result of sentiment analysis of Nigerian and Ethiopian newspaper, it is found that China's unilateral dominance in economic relations with African countries, which is one of the biggest concerns over China's African investments in the literature (Adisu, Sharkey \& Okoroafo, 2010), causes the sentiments of fear and anger to increase in Nigerian and Ethiopian newspapers. The word "unfair", which increases the feeling of sadness, also supports this result. Another negative result got as a result of the sentiment analysis is in parallel with the argument that China harms the economy of African countries. That China harms the economies of African countries, which is frequently mentioned in the literature (Kuo, 2015), was also put forward in the Nigerian and Ethiopian newspapers, and the word "damaged", which is among the words that increase the feelings of fear and anger, reflects this. However, looking at the general results, it is seen that Nigerian and Ethiopian newspapers have positive feelings about Chinese infrastructure investments and aids.

Table 4. Sentiment Analysis of Ethiopian Newspaper

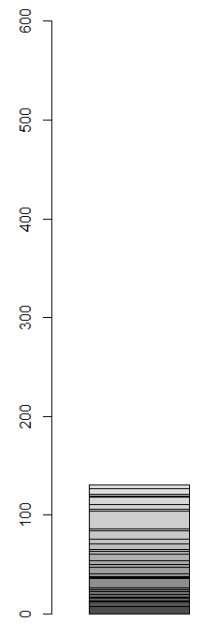

anger

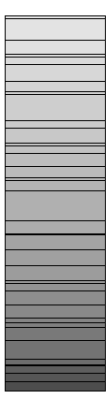

anticipation

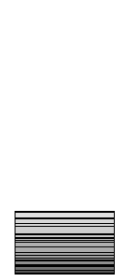

disgust

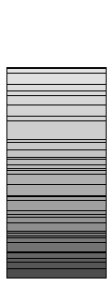

fear

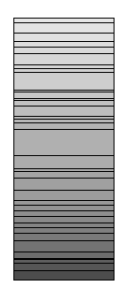

joy

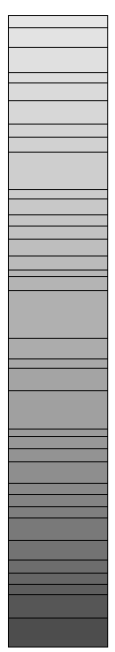

trust

Finally, it is analyzed whether the news of Nigerian and Ethiopian newspapers have positive or negative opinions about 
Chinese infrastructure aid and investments. As a result of the analysis made in this context, it is found that Nigerian and Ethiopian newspapers had a predominantly positive opinion regarding Chinese infrastructure aid and investments. On the other hand, when looking at the words that increase trust in Nigerian newspaper, it is seen that there are words such as cooperation, grant and partnership.

Table 5. Polarity Analysis of Nigerian and Ethiopian Newspapers

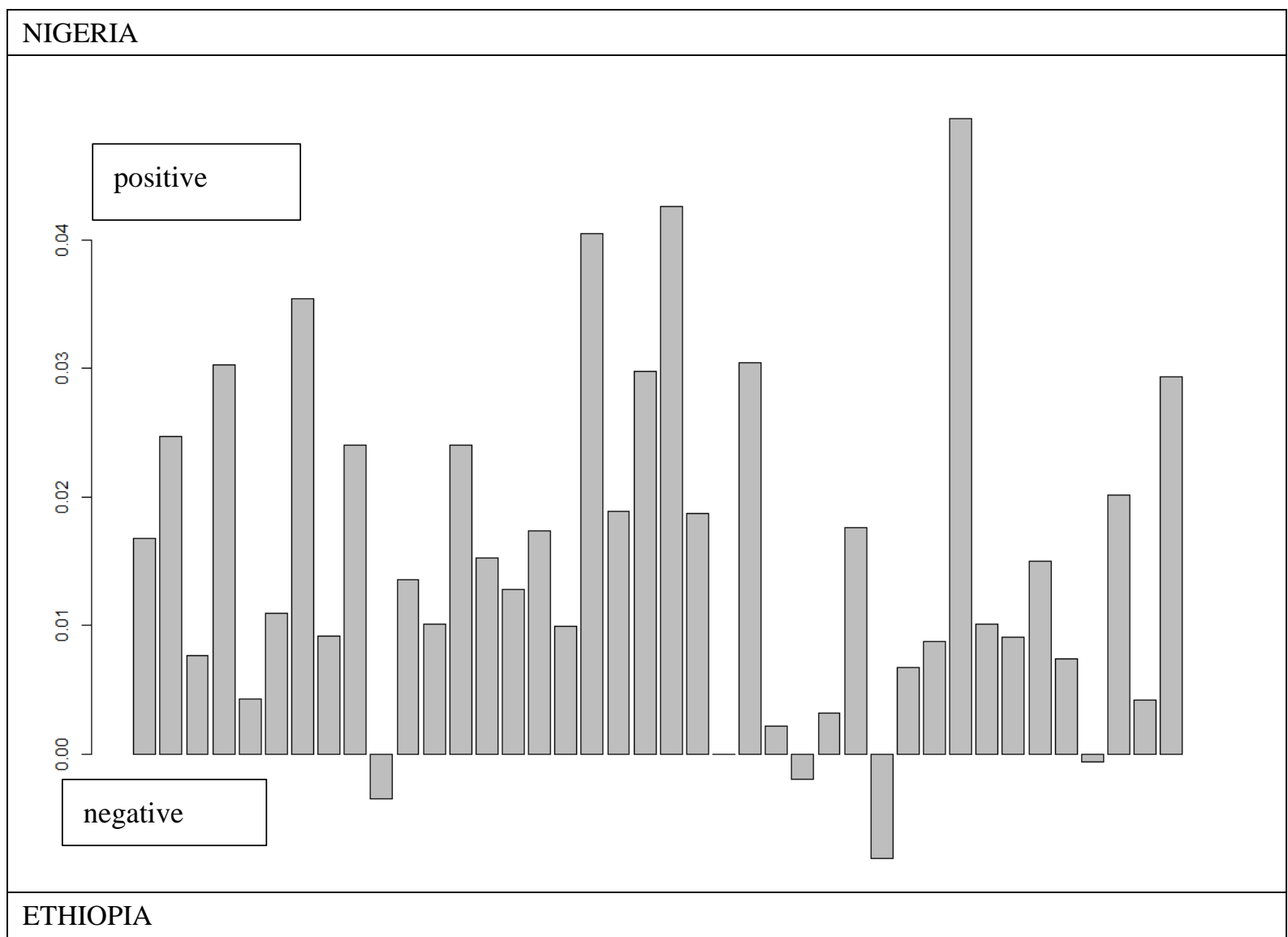




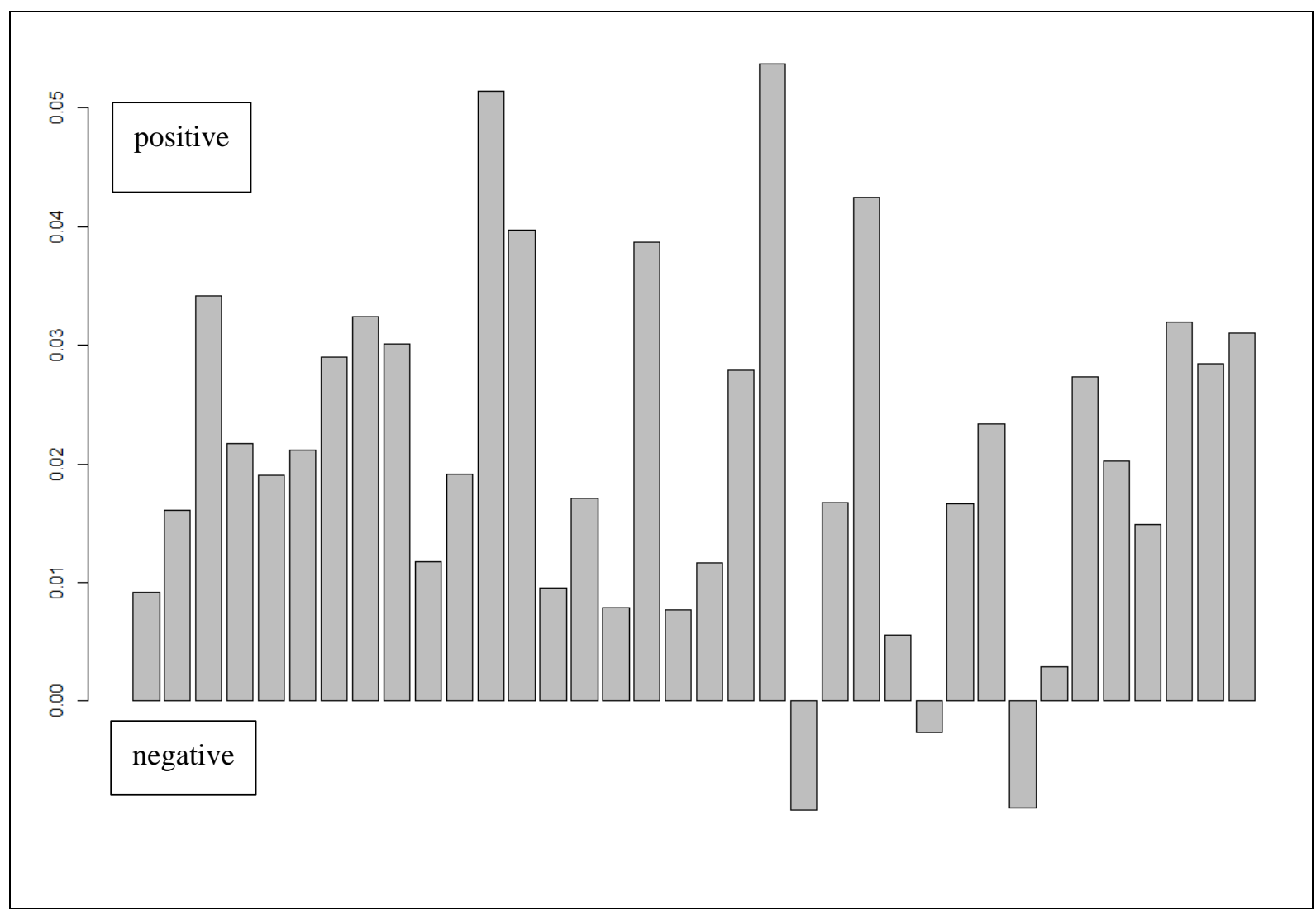

When we look at the words that increase negativity in Ethiopian newspapers, it is seen that words such as aggressive, virus, cheap, imbalance, pandemic and damages cause this negative view. It is found that the words that caused the rise of negative opinions about Chinese infrastructure services in Nigerian newspapers were words such as enslaved, cheaply, virus, pandemic, communism, illegal and slave. As a result of these findings, it has been revealed that Nigeria and Ethiopian newspapers have a positive opinion on Chinese infrastructure services and that there is trust in Chinese infrastructures in these both countries.

\section{Conclusion}

The lack of infrastructure in Africa is one of the major challenges to its development. Infrastructures are necessary ingredients to a country's prosperity and development. Building infrastructures in Africa could lead to the industrialization and integration of African countries to the world economy. As a Deloitte report on the development of infrastructure in Africa posited "Investment in infrastructure and capital projects (I\&CP) can be essential to diversify economies and promote private sector activity and industrialisation, ensuring enough jobs are created for the 12 million young people entering Africa's labour force each year" (Africa, 2018). Many countries on the continent have benefitted from Chinese infrastructure development. For instance, Angola through its cooperation with China, has been able to rebuild and rehabilitate its once shattered infrastructure caused by the 27 -year civil war. Nigeria, Africa's first economy, has cooperated with China to improve its once outdated infrastructures. Ethiopia has also taken advantage of its relationship with china to build massive infrastructures to spur its economic development. As shown by the text-based analysis, Nigerians and Ethiopians newspapers have a positive view of Chinese infrastructures. Throughout our analysis, it was found that Nigerian and Ethiopian newspapers had a predominantly positive opinion of Chinese infrastructure aid and investments.

Even though the views on china's infrastructure development are positive in general, there are some controversies related to Chinese engagement with Africa. Issues of concern are the debt trap issue; whereby poor African countries are induced into taking predatory loans to build expensive infrastructures with the aim of taking control of these assets when the borrowers cannot pay back. This debt trap could also be used as a political leverage by Beijing twisting indebted countries arm into subscribing to the one China policy or supporting it at the international level. The massive number of Chinese labours going to Africa instead of Chinese companies using the young and abundant African labour is also a matter of concern (Carr, 2020). Security is also another issue of concern. Some studies suggest that China could use the infrastructures built as an outlet to spy on African countries. A report by the French News Outlet Le 
Monde stipulated that China was spying on African countries through the computer system it has installed at the African Union headquarter. A ramification of this security issue could also be the potential risk related to digital colonialism by China on the continent.

However, it is necessary to point out that Chinese loans for infrastructure development are important sources of development for African countries. They are above all alternative responses to western conditionality attached to financial help. Besides, that western countries showed little interest in investing in these development projects could explain Chinese growing influence in that domain. Furthermore, the Belt and Road Initiative has helped to connect African countries to one another and also to the rest of the world. The positive impact that these infrastructures have on the integration of African countries into the world market and on populations explains the overall positive perspective people have on Chinese development of African infrastructures.

\section{References}

Adisu, K., Sharkey, T., \& Okoroafo, S. C. (2010). The impact of Chinese investment in Africa. International Journal of Business and Management, 5(9), 3. https://doi.org/10.5539/ijbm.v5n9p3

African Development Bank (ADB). (2018). Africa's infrastructure: Great potential but little impact on inclusive growth (Chapter 3).

Ajakaiye, O., \& Ncube, M. (2010). Infrastructure and economic development in Africa: An overview. Journal of African economies, 19 (suppl_1), i3-i12. https://doi.org/10.1093/jae/ejq003

Alemayehu G., \& Atenafu G. M. (February 2010). Impact of China-Africa Investment Relations: Case Study of Ethiopia. African Economic Research, AERC, Nairobi. Retrieved from https://aercafrica.org/wp-content/uploads/2018/06/china6.pdf

Aschauer, D. A. (1990). Why is infrastructure. Industry Week, 21-50.

Asiamah, G., Sambou, O., \& Bhoojedhur, S. (2021, January 15). Analysis |Are African governments doing enough to help young people? Here's what Afrobarometer surveys reveal. Washington Post. Retrieved from https://www.washingtonpost.com/politics/2021/01/15/are-african-governments-doing-enough-help-young-people-h eres-what-afrobarometer-surveys-reveal/

Ayogu, M. (2007). Infrastructure and economic development in Africa: a review. Journal of African Economies, 16(suppl_1), 75-126. https://doi.org/10.1093/jae/ejm024

BBC. BBC World Service Poll. Accessed 2021/07/8. Retrieved from http://downloads.bbc.co.uk/mediacentre/country-rating-poll.pdf

Bluhm, R., Dreher, A., Fuchs, A., Parks, B., Strange, A., \& Tierney, M. J. (2018). Connective financing: Chinese infrastructure projects and the diffusion of economic activity in developing countries. https://doi.org/10.2139/ssrn.3262101

Bom, P. R., \& Ligthart, J. E. (2009). How Productive is Public Capital?: A Meta-regression Analysis. Georgia State Univ., Andrew Young School of Policy Studies.

Cabestan, J. P. (2019). Beijing's 'Going Out'Strategy and Belt and Road Initiative in the Sahel: The case of China's growing presence in Niger. Journal of Contemporary China,28(118), 592-613. https://doi.org/10.1080/10670564.2018.1557948

Calderón, C., \& Servén, L. (2008). Infrastructure and economic development in Sub-Saharan Africa. https://doi.org/10.1596/1813-9450-4712

Carr, E. (September 4th, 2020). The US Versus Chinese Investment In Africa. Forbes. Retrieved at The US Versus Chinese Investment In Africa (forbes.com).

Catalinac, A. (2016). From pork to policy: The rise of programmatic campaigning in Japanese elections. The Journal of Politics, 78(1), 1-18. https://doi.org/10.1086/683073

Chakrabarty, M. (2016). Ethiopia-China economic relations: A classic win-win situation? World Review of Political Economy, 7(2), 226-248. https://doi.org/10.13169/worlrevipoliecon.7.2.0226

Cohen, B. (1963). Press and Foreign Policy. PRINCETON, NEW JERSEY: Princeton University Press. Retrieved June 15, 2021, from http://www.jstor.org/stable/j.ctt183q0fp

Daniella van Leggelo-Padilla (April 2017).Why We Need to Close the Infrastructure Gap in Sub-Saharan Africa. Retrieved from

https://www.worldbank.org/en/region/afr/publication/why-we-need-to-close-the-infrastructure-gap-in-sub-saharan- 
africa

Deloitte Africa, “Africa construction trends report”, 2018.

Dennis Q.(23 April 2020). Nigerians living near a major Belt and Road project grew more positive toward China after it was completed. Pew Research Center. Retrieved from https://www.pewresearch.org/fact-tank/2020/04/23/nigerians-living-near-a-major-belt-and-road-project-grew-more -positive-toward-china-after-it-was-completed/

Dictionary.com. (Ed.) (2021). Infrastructure: Define Infrastructure at Dictionary.com. Retrieved from https://www.dictionary.com/browse/infrastructure

Donou-Adonsou, F., \& Lim, S. (2018). On the importance of Chinese investment in Africa. Review of development finance, 8(1), 63-73. https://doi.org/10.1016/j.rdf.2018.05.003

Dumont, R. (1963). L'Afrique Noire est mal partie. In Annales de Geographie (vol.72, No.393, pp.620-621). Societe de Geographie. https://doi.org/10.3406/geo.1963.16499

Economic, C. A. (2013). China-Africa economic and trade cooperation.

Ehizuelen, M. M. O., \& Abdi, H. O. (2018). Sustaining China-Africa relations: Slotting Africa into China's one belt, one road initiative makes economic sense. Asian Journal of Comparative Politics, 3(4), 285-310. https://doi.org/10.1177/2057891117727901

Evans, P., \& Karras, G. (1994). Is government capital productive? Evidence from a panel of seven countries. Journal of Macroeconomics, 16(2), 271-279. https://doi.org/10.1016/0164-0704(94)90071-X

Fei, D. (2020). Variegated work regimes of Chinese investment in Ethiopia. World Development, $135,105049$. https://doi.org/10.1016/j.worlddev.2020.105049

Folashade, S., \& Edem E. S. (22 November 2020). What Africans really think about China's role in Africa. Quartz Africa. Retrieved from https://qz.com/africa/1936504/what-africans-really-think-about-chinas-role-in-africa/

Foster, V. (2009). Building bridges: China's growing role as infrastructure financier for Sub-Saharan Africa (Vol. 5). World Bank Publications. https://doi.org/10.1596/978-0-8213-7554-9

Fulmer, J. (2009). What in the world is infrastructure. PEI Infrastructure investor, 1(4), 30-32.

Gildfred, A., Ousmane D. S., \& Sadhiska, B. ( January 15, 2021). Are African governments doing enough to help young people? Here's what Afrobarometer surveys reveal. Washingtonpost. Retrieved from https:/www.washingtonpost.com/politics/2021/01/15/are-african-governments-doing-enough-help-young-people-h eres-what-afrobarometer-surveys-reveal/

Gramlich, E. M. (1994). Infrastructure investment: A review essay. Journal of economic literature, 32(3), 1176-1196.

Haile, S. (2004). Population, development, and environment in Ethiopia. Environmental change and security project report, 10, 43-51.

Hailemariam, T. W., Ethiopia, S. S., Alamdo, A. G., \& Hailu, H. E. (2020). Emerging Nutritional Problem of Adult Population: Overweight/Obesity and Associated Factors in Addis Ababa City Communities, Ethiopia-A Community-Based Cross-Sectional Study. Journal of Obesity, 2020. https://doi.org/10.1155/2020/6928452

Hanauer, L., \& Morris, L. J. (2014). China in Africa: Implications of a deepening relationship. Santa Monica, CA: RAND Corporation. https://doi.org/10.7249/RB9760

Haroz, D. (2011). China in Africa: Symbiosis of exploitation. Fletcher F. World Aff., 35, 65.

Hu, M., \& Liu, B. (2004, July). Mining opinion features in customer reviews. In AAAI (Vol. 4, No. 4, pp. 755-760).

Imanche, S. A., Ze, T., Ayom, M. C., \& Dalibi, S. G. (2021). An Assessment of Nigerians Perception towards Chinese Foreign Direct Investments and Its Acceptability in Nigeria. Open Journal of Business and Management, 9(3), 1151-1168. https://doi.org/10.4236/ojbm.2021.93062

Indira, C., \& Alex, V. (2008). Angola and China: A Pragmatic Partnership. London: Chatham House.

Jenni, M. (September 3, 2018). Skyscrapers, trains and roads: How Addis Ababa came to look like a Chinese city.CNN Style. Retrieved from https:/edition.cnn.com/style/article/addis-ababa-china-construction-style/index.html

Kuo, S. (2015). China's investment in Africa- The African perspective. Forbes Journal.

Laura, S., \& Courtney, J. (9 october 2018). Internet Connectivity Seen as Having Positive Impact on Life in Sub-Saharan Africa.But digital divides persist. Pew Research Center. Retrieved from 
https://www.pewresearch.org/global/2018/10/09/internet-connectivity-seen-as-having-positive-impact-on-life-in-su b-saharan-africa/

Leggelo-Padilla, D. V. (2017). Why We Need to Close the Infrastructure Gap in Sub-Saharan Africa.

Lewis, K. (24 May 2012), Better infrastructure brings economic growth, IPP Digital, State Department's Bureau of International Information Programs (IIP). Retrieved from http://iipdigital.usembassy.gov/st/english/article/2012/05/201205246230.html\#axzz2uyyNj6gi

Linda, Y. (July 16, 2019). Top 5 Benefits of The Internet In Developing Countries. The Borgen Project. Retrieved from https://borgenproject.org/top-5-benefits-of-the-internet-in-developing-countries/

Lindstedt, N. C. (2019). Structural Topic Modeling for Social Scientists: A Brief Case Study with Social Movement Studies Literature, 2005-2017. Social Currents, 6(4), 307-318. https://doi.org/10.1177/2329496519846505

Manning, C. D., Raghavan, P., \& Schütze, H. (2008). Xml retrieval. In Introduction to Information Retrieval. Cambridze University Press. https://doi.org/10.1017/CBO9780511809071.011

Mariama, S. (September 6, 2018). Figures of the week: Chinese investment in Africa. Africa in Foucs. Retrieved from https://www.brookings.edu/blog/africa-in-focus/2018/09/06/figures-of-the-week-chinese-investment-in-africa/

Marshall, A. (2011). China's mighty telecom footprint in Africa. ELearning Africa News Portal. Retrieved from http://www.newsecuritylearning.com/index.php/feature/75-chinas-mighty-telecom-footprint-in-africa

McLaren, L., Boomgaarden, H., \& Vliegenthart, R. (2018). News coverage and public concern about immigration in Britain. International Journal of Public Opinion Research, 30(2), 173-193. https://doi.org/10.1093/ijpor/edw033

Meibo, H., \& Xie, Q. I. (2012). Forum on China-Africa Cooperation: development and prospects. African East-Asian Affairs, 74. https://doi.org/10.7552/74-0-65

Michel, S., \& Beuret, M. (2009). China safari: On the trail of Beijing's expansion in Africa. Bold Type Books.

Mogopodi, L., Anyway, C., Mina, O., \&Romaric, S. (24 October 2016). China's growing presence in Africa wins largely positive popular reviews. Afrobarometer. Retrieved from

https://afrobarometer.org/sites/default/files/publications/Dispatches/ab_r6_dispatchno122_perceptions_of_china_in _africa1.pdf

Morlin-Yron, S. (2017). All aboard! The Chinese-funded railways linking East Africa. CNN, January, 17.

Nathan, L. (2000). The Four Horsemen of the Apocalypse: The Structural Causes of Crisis and Violence in Africa. Peace \& Change, 25(2), 188-207. https://doi.org/10.1111/0149-0508.00150

Nicholas, F. (2017). Chinese investors in Ethiopia: the perfect match?. Chinese Infrastructure Investment in Ethiopia. Borgen. Retrieved from Chinese Infrastructure Investment in Ethiopia - BORGEN (borgenmagazine.com)

Okereke, O. C. (2017). Sustainability is a Critical Criterion for Success in the Current Nigerian Railways Projects.

Olamide, K. S. (May 31, 2017). China Building Friendship through Infrastructure Financing in Nigeria. Chinadaily.com. Retrieved from http://www.chinadaily.com.cn/opinion/2017beltandroad/2017-05/31/content_29562595.htm

Pang, B., \& Lee, L. (2008, August). Using very simple statistics for review search: An exploration. In Coling 2008: Companion volume: Posters (pp. 75-78).

Pew Research Center, Opinion of China. (2021). Do you have a favorable or unfavorable view of China? https://www.pewresearch.org/global/database/indicator/24/ (accessed July 8, 2021)

Pröellochs, N., \& Feuerriegel, S. (2019). Reinforcement Learning: A Package to Perform Model-Free Reinforcement Learning. R. Journal of Open Source Software, 4(38), 1087. https://doi.org/10.21105/joss.01087

Roberts, M. E., Stewart, B. M., \& Tingley, D. (2019). Stm: An R package for structural topic models. Journal of Statistical Software, 91(1), 1-40. https://doi.org/10.18637/jss.v091.i02

Seyoum, M., \& Lin, J. (2015). Private Chinese investment in Ethiopia: determinants and location decisions. Journal of International Development, 27(7), 1223-1242. https://doi.org/10.1002/jid.3025

Shaban, A. R. A. (2020). One to five: Ethiopia gets four new federal working languages. Africanews.

Shen, X. (2015). Private Chinese investment in Africa: Myths and realities. Development Policy Review, 33(1), 83-106. https://doi.org/10.1111/dpr.12093

Shirley, Y. Z. (21 April, 2021). Why substantial Chinese FDI is flowing into Africa. The London School of Economic 
and Political Science. Retrieved from https://blogs.lse.ac.uk/africaatlse/2021/04/02/why-substantial-chinese-fdi-is-flowing-into-africa-foreign-direct-inve stment/

Silver, L., Devlin, K., \& Huang, C. (2019). How People around the World View China. Pew Research Center's Global Attitudes Project. Retrieved from https://www.pewresearch.org/global/2019/12/05/attitudes-toward-china-2019/

Taye, M. T., Tadesse, T., Senay, G. B., \& Block, P. (2016). The grand ethiopian renaissance dam: Source of cooperation or contention? Journal of Water Resources Planning and Management, 142(11), 02516001. https://doi.org/10.1061/(ASCE)WR.1943-5452.0000708

Torrisi, G. (2009). Public infrastructure: definition, classification and measurement issues. Economics, Management, and Financial Markets, 4(3), 100-124.

Vivien, F., \& Elvira, M. (2010). Ethiopia's Infrastructure: A Continental Perspective. The International Bank for Reconstruction and Development/The World Bank. Country Report, 3.

Wickham, H. (2021). Rvest: Easily Harvest (Scrape) Web Pages. Retrieved from https://CRAN.R-project.org/package=rvest

Zajontz, T. (2021). The Chinese infrastructural fix in Africa: Lessons from the Sino-Zambian 'road bonanza'. Oxford Development Studies, 1-17. https://doi.org/10.1080/13600818.2020.1861230

Zegeye, A. A. (2000). US public infrastructure and its contribution to private sector productivity. US Department of Labor, Bureau of Labor Statistics, Office of Productivity and Technology.

\section{Copyrights}

Copyright for this article is retained by the author(s), with first publication rights granted to the journal.

This is an open-access article distributed under the terms and conditions of the Creative Commons Attribution license which permits unrestricted use, distribution, and reproduction in any medium, provided the original work is properly cited. 